\section{Dr George McAdam}

\author{
Maj J D C Bennett \\ BSc, FRCS, DCH, DHMSA, FSA, RAMC \\ Senior Specialist in Otolaryngology \\ Queen Elizabeth Military Hospital, Woolwich, London SE18 4QH
}

\author{
Dr J Bezzina \\ Dip Arch, Dip Bibl, BA HED \\ Lecturer
}

Faculty of Theology University of Malta

A hitherto little known army surgeon has been commemorated by having a street in Gozo named after him for his work during the epidemic of plague 1813-14 in Malta. History records quite a few distinguished military medical men but they are acknowledged or remembered in other ways. Military prowess and valour bring medals - in which field the Royal Army Medical Corps and its predecessors are well represented. Others, such as Bruce, may be immortalised by having their discovery named after them. George McAdam's work fell into neither of these categories, but nevertheless, the Street Naming Committee of Gozo decided to show gratitude for his work in the early nineteenth century by naming a street after him in 1991 .

The Maltese archipelago consists of three islands known from north to south as Gozo, Comino and Malta. They passed informally under British protection on 5 September 1800 . Lying at the centre of the Mediterranean trade routes they had immense strategic value, but this unfortunately meant that despite quarantine measures the large number of ships calling at the Grand Harbour brought the bubonic plague which had broken out in Constantinople in 1812. From there the infection soon passed to Gozo, it was thought through the unwitting carriage of a present of silk. Communications between Gozo and Malta were promptly cut off and a military detachment was sent to provide a cordon around the infected village of Xaghra. Despite these precautions the plague spread and it was decided by the government that a manor house be requisitioned and converted into a hospital.

This took place under a military doctor, George McAdam, who despite the known risks had volunteered for the job. He had been commissioned as an Assistant Surgeon to the 24th Dragoons in 1797 , to be retired in 1799. He returned to the colours in 1802 and was promoted to Surgeon in 1805 , becoming Physician to the Forces in 1813. The Tal-Fewdu plague hospital was situated on the outskirts of Xaghra and completed by 19 March 1814, less than three weeks after the first plague deaths on the island. On McAdam's advice a tented camp was also set up. On 31 March people living in the

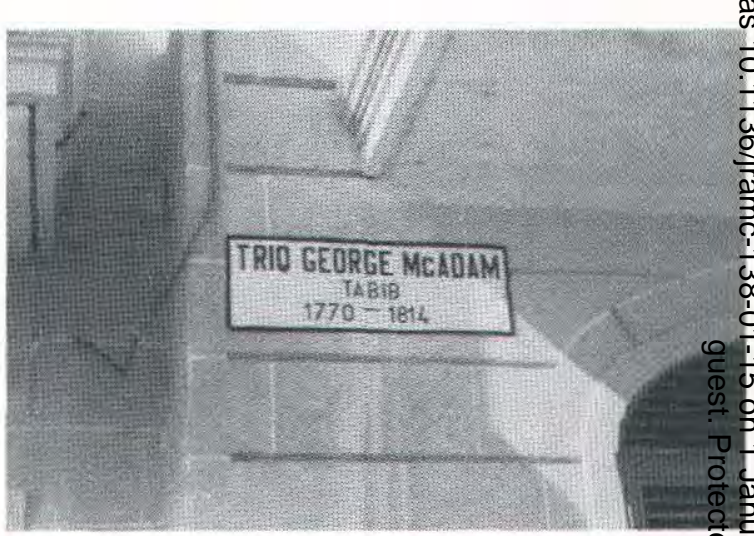

Fig 1. Commemoration street name plate (tabib $=\stackrel{2}{2}$ doctor)

houses of known victims were moved there for obse 8 tion. Another area was enclosed for their cattle onn other animals and the whole area sealed by a miliogro cordon. Unfortunately McAdam, whose duties lead to move freely about in contact with patients, fell pred to the disease and died on 5 May 1814. However the plague remained localised to the village of Xaghra. The last death was on the 28 May and by 14 Septembr $\overrightarrow{0}$ communications between Gozo and Malta wer restored.

In his work at the village of Xaghra he put into praco tical use his organisational capacity drawing on militar resources. Rather than judging his work from the cup rent standpoint of medical knowledge, let us consider $\mathbb{\Psi}$ in its historical context. Much of current medical opir. ion at the time lay with the miasma theory of disease. was considered that diseases emanated from a. "infected atmosphere". Others held that plague was $\frac{\pi}{3}$ contagious disease. However contagion was traced to the most astonishing circumstances - for examplo through a pair of new shoes which had not been hung for a fortnight before being worn. A total of 104 vip lagers died during the plague of 1814 but the work McAdam has been commemorated in 1991 by a Xaghin street being named after him (Fig 1). 